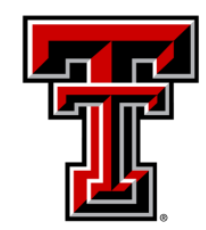

TEXAS TECH UNIVERSITY

Libraries"

\title{
NeW Strategy To Access EnantioenRiChed CycloheXadienones: KINETIC RESOLUTION OF PARA-QUINOLS BY ORGANOCATALYTIC THIOL- Michael Addition Reactions
}

\section{The Texas Tech community has made this publication openly available. Please share how this access benefits you. Your story matters to us.}

\begin{tabular}{|l|l|}
\hline Citation & $\begin{array}{l}\text { Ting Tang, Nicholas G. Moon, Lydia McKay, and Andrew. M. Harned. } \\
\text { New Strategy to Access Enantioenriched Cyclohexadienones: } \\
\text { Kinetic Resolution of para-Quinols by Organocatalytic Thiol-Michael } \\
\text { Addition Reactions. ACS Omega 2018 3 (11), 15492-15500 DOI: } \\
\text { https://doi.org/10.1021/acsomega.8b01787 }\end{array}$ \\
\hline Citable Link & $\underline{\text { https://hdl.handle.net/2346/82353 }}$ \\
\hline Terms of Use & $\underline{\text { CC-BY }}$ \\
\hline
\end{tabular}




\title{
New Strategy To Access Enantioenriched Cyclohexadienones: Kinetic Resolution of para-Quinols by Organocatalytic Thiol-Michael Addition Reactions
}

\author{
Ting Tang, ${ }^{\dagger}$ Nicholas G. Moon, ${ }^{\ddagger, \S}$ Lydia McKay, ${ }^{\dagger, \mathbb{I l}}$ and Andrew. M. Harned ${ }^{*}{ }^{\dagger} \odot$
}

${ }^{\dagger}$ Department of Chemistry \& Biochemistry, Texas Tech University, 1204 Boston Avenue, Lubbock, Texas 79409-1061, United

States

${ }^{\ddagger}$ Department of Chemistry, University of Minnesota—Twin Cities, 207 Pleasant Street SE, Minneapolis, Minnesota 55455, United States

Supporting Information

ABSTRACT: Existing stereoselective routes to 2,5-cyclohexadienones involve either desymmetrization of an achiral substrate or have attempted to perform an asymmetric dearomatization of a phenol. Herein, we report proof-ofprinciple experiments aimed at developing a kinetic resolution as an alternative method for accessing enantioenriched 2,5cyclohexadienones. More specifically, chiral bifunctional thiourea catalysts were used to promote the addition of 2 thionapthalene into unsymmetric para-quinols. The selectivity of the kinetic resolution was found to be quite sensitive to substitution around the substrate.

\section{INTRODUCTION}

Cyclohexadienones continue to serve as useful reactive intermediates and building blocks for organic synthesis ${ }^{1,2}$ and medicinal chemistry. ${ }^{3}$ Interest in these compounds stems from their dense functionality and the fully substituted carbon atom that is necessarily present. Over the past $10-15$ years, there has been a steady interest in performing asymmetric transformations involving 2,5-cyclohexadienones, and two main strategies have emerged for realizing this goal. The first involves preparing an achiral dienone (e.g., through iodine(III)-mediated oxidative dearomatization of a symmetric phenol) and then performing a desymmetrization of the resulting achiral dienone (Figure 1A)., ${ }^{4,5}$ Numerous examples of dienone desymmetrization have been reported and many afford products with high enantioenrichment. A second strategy involves performing an asymmetric oxidative dearomatization on an unsymmetric phenol (Figure 1B). ${ }^{6-8}$ This approach has the potential to be very powerful as it provides direct access to enantioenriched, substituted dienones. However, this route remains underdeveloped for several reasons. ${ }^{9,10}$ Although some progress has been made in accessing enantioenriched 2,5-cyclohexadienones in this manner, ${ }^{11}$ there is still no single chiral iodoarene catalyst capable of delivering high selectivity with a wide range of substrates.

The strategies outlined in Figure $1 \mathrm{~A}, \mathrm{~B}$ are both viable options for the preparation of enantioenriched products from a 2,5-cyclohexadienone. In some circumstances, a desymmetrization route may be more efficient. ${ }^{12}$ In others, using a chiral dienone derivative would be a better choice. ${ }^{13}$ With a
(A)

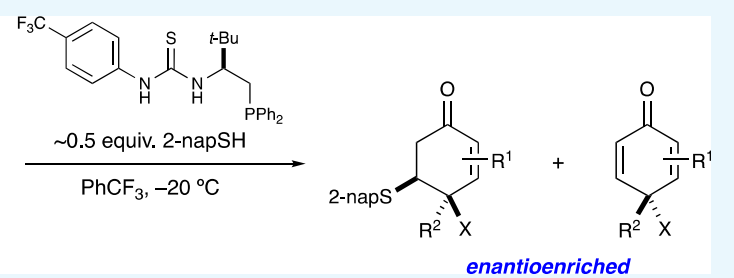<smiles>[R]c1ccc(O)cc1</smiles>

(B)<smiles>[R]c1ccc(O)c([R])c1</smiles>

(C)

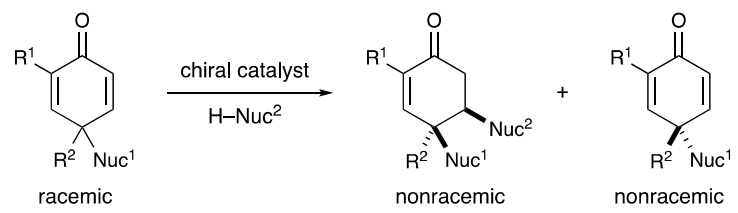

Figure 1. Strategies for performing asymmetric transformations with 2,5-cyclohexadienones. (A) Asymmetric desymmetrization of 2,5cyclohexadienones. (B) Asymmetric oxidative dearomatization to chiral 2,5-cyclohexadienones. (C) Kinetic resolution of 2,5-cyclohexadienones (this work).

Received: July 26, 2018

Accepted: October 31, 2018

Published: November 14, 2018 
multitude of desymmetrization options available, ${ }^{4,5}$ the question then becomes, is there another way to access chiral, nonracemic dienones without using a chiral iodoarene catalyst? Owing to the ready availability of racemic 2,5-cyclohexadienones from substituted phenols, we hypothesized that the development of a kinetic resolution approach might be such a solution (Figure 1C). To the best of our knowledge, 2,5cyclohexadienones have not previously been subjected to kinetic resolution reactions. Herein, we report our initial proofof-principle experiments in which a thiol-Michael reaction ${ }^{14-16}$ was used for the kinetic resolution of para-quinols.

\section{RESULTS AND DISCUSSION}

Our initial experiments focused on the resolution of 2,4dimethylquinol (1a) using $p$-toluenethiol ( $p$-TolSH) as a nucleophile (Scheme 1). Cinconidine was used as a catalyst for

\section{Scheme 1}

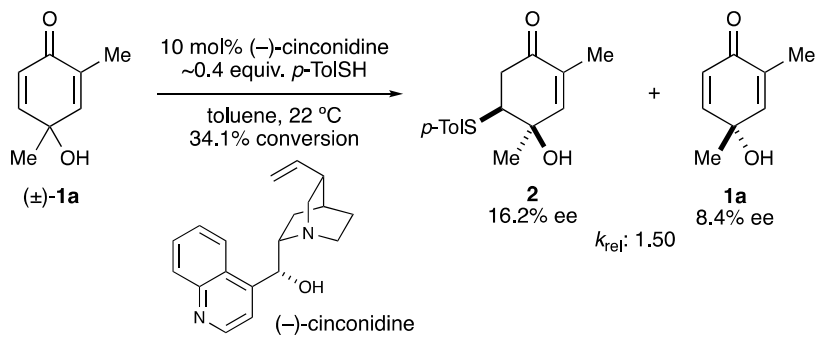

these experiments as it is a readily available chiral base. The conversion was determined from the enantiomeric excess of the product and recovered starting material by using eq 1 , which is a rearranged form of one reported by Kagan and Fiaud. $^{17}$

$$
\text { conversion }=\frac{\mathrm{ee}_{\mathrm{SM}}}{\mathrm{ee}_{\mathrm{SM}}+\mathrm{ee}_{\mathrm{PDT}}}
$$

This method has previously been used to obtain accurate conversions in kinetic resolution reactions. ${ }^{18}$

In kinetic resolutions, the $\%$ ee of the product and unreacted starting material is directly related to the overall conversion. For this reason, it is more useful to compare the $k_{\text {rel }}$ values of different reactions, as these are directly related to the free energy difference of the diastereomeric transition states (eq 2). ${ }^{19}$

$$
k_{\text {rel }}=k_{\text {fast }} / k_{\text {slow }}=\mathrm{e}^{\Delta \Delta G^{\ddagger} / R T}
$$

Assuming a given kinetic resolution is first-order or pseudofirst-order in reactants, the calculated $k_{\text {rel }}$ value should be the same at all conversions irrespective of using the \% ee of the starting material or product. We calculated the $k_{\text {rel }}$ values using the $\%$ ee, as measured by chiral high-performance liquid chromatography (HPLC), of recovered starting material according to the following equation ${ }^{17}$

$$
k_{\mathrm{rel}}=\frac{\ln \left[(1-C)\left(1-\mathrm{ee}_{\mathrm{SM}}\right)\right]}{\ln \left[(1-C)\left(1+\mathrm{ee}_{\mathrm{SM}}\right)\right]}
$$

A screen of several solvents $\left[\mathrm{CH}_{2} \mathrm{Cl}_{2}, \mathrm{CHCl}_{3}, \mathrm{CCl}_{4}\right.$, tetrahydrofuran (THF), $\mathrm{Et}_{2} \mathrm{O}, \mathrm{PhCF}_{3}$, toluene] revealed toluene provided the highest $k_{\text {rel }}$ value. Performing the reaction at lower temperatures $\left(0,-50{ }^{\circ} \mathrm{C}\right)$ provided no significant improvement. In all cases, the nucleophile was found to add only to the less-substituted double bond of the dienone (to give 2), ${ }^{a}$ owing to the electron-releasing nature of the methyl group in the 2-position. ${ }^{20}$ Despite the low selectivity afforded by cinconidine, these results were quite promising as we were at least observing some kinetic discrimination of the two enantiomers.

In order to identify a more selective catalyst, we turned our attention to bifunctional thiourea catalysts. ${ }^{21} \mathrm{We}$ also determined that replacing $p$-TolSH with 2-napthalenethiol (2-napSH) led to somewhat improved selectivity. Consequently, we used this nucleophile to screen different chiral thiourea catalysts (Scheme 2 and Table 1). As expected,

Table 1. Screening of Bifunctional Thiourea Catalysts ${ }^{a}$

\begin{tabular}{llcrrr} 
entry & catalyst & \% conversion $^{b}$ & \% ee $\mathbf{3}^{c}$ & $\%$ ee $\mathbf{1 \mathbf { a } ^ { c }}$ & \multicolumn{1}{c}{$k_{\text {rel }}{ }^{d}$} \\
$\mathbf{1}$ & 4a & 40.9 & 59.6 & 41.2 & 5.84 \\
2 & 4b & 38.2 & 59.1 & 36.5 & 5.50 \\
3 & 4c & 54.9 & 50.5 & 61.4 & 5.50 \\
4 & 4d & 50.7 & 60.8 & 62.6 & 7.65 \\
5 & 4e & 70.7 & 22.9 & 55.3 & 2.58 \\
6 & 4f & 38.0 & 38.9 & 23.8 & 2.83 \\
7 & 4g & 39.7 & 65.5 & 43.1 & 7.25 \\
8 & 4h & 40.5 & 70.3 & 47.9 & 9.16
\end{tabular}

${ }^{a}$ See Scheme 2 for conditions. Catalyst concentration was 0.0025 $\mathrm{mmol} / \mathrm{mL}$. ${ }^{b}$ Determined using eq $1 .{ }^{c}$ Determined by chiral HPLC analysis. ${ }^{d}$ Determined using eq 3.

thiourea catalysts $\mathbf{4 a}$ and $\mathbf{4 b}$, which incorporate a basic amine, did offer improved performance (entries 1 and 2). We also had the opportunity to screen catalysts $\mathbf{4 c}$ and $\mathbf{4 d}$ in which the amine was replaced with a diaryl phosphine group. We were

\section{Scheme 2}

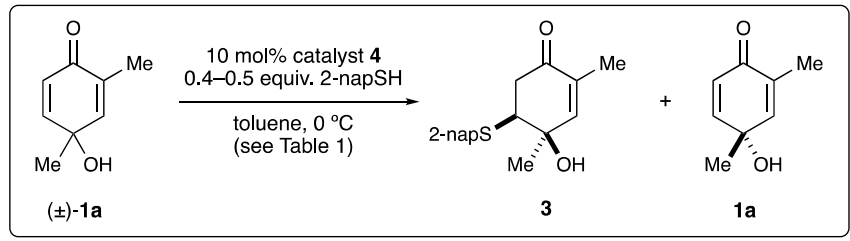<smiles>[R]C(Cc1ccccc1)NC(=S)Nc1cc(C(F)(F)F)cc(C(F)(F)F)c1</smiles><smiles>CC(C)C(Cc1ccccc1)NC(=S)Nc1ccc(F)cc1</smiles><smiles>CC(C)C(Cc1ccccc1)NC(=S)Nc1ccc(C(F)(F)F)cc1</smiles><smiles>CC(C)(C)C(Cc1ccccc1)NC(=S)Nc1ccc([N+](=O)[O-])cc1</smiles><smiles>CC(C)(C)C(Cc1ccccc1)NC(=S)Nc1ccc(C(F)(F)F)cc1</smiles><smiles>CCC1CN2CCC1CN2C(NC(=S)Nc1cc(C(F)(F)F)cc(C(F)(F)F)c1)c1ccnc2ccc(OC)cc12</smiles><smiles>CN(C)C1CCCC[C@H]1NC(=S)Nc1cc(C(F)(F)F)cc(C(F)(F)F)c1</smiles>
$4 \mathrm{~d}, \mathrm{R}=t-\mathrm{Bu}$

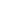


surprised to find that these catalysts offered somewhat improved performance (entries 3 and 4) compared to $\mathbf{4 b}$. The substitution of the $N$-arylthiourea does have an influence on the selectivity (entries 5-7). Eventually, we decided that catalyst $\mathbf{4 h}$, although not completely ideal with respect to selectivity (entry 8 ), was sufficient to carry out further studies.

Both catalyst classes generated a single diastereomer of the product, in which the thiol was added syn to the hydroxyl group. ${ }^{a}$ This was assigned on the basis of coupling constant analysis and comparison to a similar, known compound. ${ }^{15 \mathrm{~b}}$ The syn addition can be rationalized using the stereoelectronic effects proposed by Paquette and co-workers. ${ }^{22}$ This result also indicates that conjugate addition of the phosphine moiety in catalysts $\mathbf{4 c}-\mathbf{h}$ to the electron-deficient alkene is likely not part of the mechanistic pathway. We did not observe any change in enantioselectivity over time, indicating that thiol addition was irreversible under these conditions.

A number of potential catalysts resulted in little-to-no conversion of quinol 1a (Figure 2). These results are<smiles>CCCCCCCOC(CC(NC(=S)Nc1cc(C(F)(F)F)cc(C(F)(F)F)c1)C(C)C)=NP</smiles>

$4 \mathbf{i} \quad \mathrm{Bn}$<smiles>FC(F)(F)c1cc(NC(=S)N[C@H]2CCCc3cccc(P)c32)cc(C(F)(F)F)c1</smiles>

$4 \mathbf{k}$

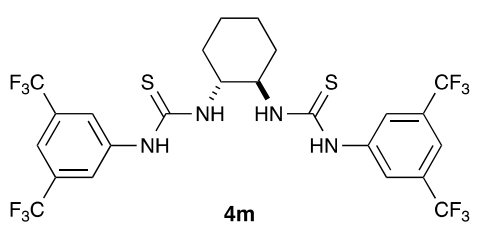

Figure 2. Thiourea catalysts that gave poor conversion. instructive with regard to the mechanism and how the various reaction components interact with each other. The failure of iminophosphorane $\mathbf{4} \mathbf{i}$ and phosphine oxide $4 \mathbf{j}$ shows that phosphine plays a key role in the reaction, likely as a base or hydrogen-bond acceptor. Potential catalysts $4 \mathbf{k}$ and $\mathbf{4 l}$ are less conformationally flexible than catalysts $4 c-4 h$, revealing that proper positioning of the phosphine is critically important. At the same time, catalyst $4 \mathbf{k}$ is a triaryl phosphine and will likely be somewhat less basic than diarylphosphines $\mathbf{4 c - 4 h}$. At this time, it is not clear why phosphine $\mathbf{4 l}$ gave poor conversion, when amine $4 \mathrm{~b}$ was a competent catalyst. The requirement of having both a Lewis basic group and a hydrogen-bond donor is further supported by the poor results observed with bis(thiourea) $\mathbf{4 m}$ and bis(sulfonamide) $4 \mathrm{n}$.

As thiourea-based catalysts have a tendency to aggregate in solution, ${ }^{23,24}$ we decided to investigate how changing the concentration of the reaction components affects the selectivity of the kinetic resolution. This was done using catalyst $4 \mathrm{~d}$, prior to identifying catalyst $4 \mathrm{~h}$ as being superior. In these experiments (Table 2), different volumes of solvent were used while holding the amount of catalyst and reactants constant. As shown in entries 1-4, dilution of the reaction components resulted in increasing $k_{\text {rel }}$ values. Entries 4-6 show that modest gains in selectivity can be achieved by using lower reaction temperatures.

Having settled on catalyst $\mathbf{4 h}$ as our optimal catalyst, we decided to reinvestigate the influence of solvent (Table 3, entries 1-6) and other reaction conditions. On the basis of these results, it was clear that trifluorotoluene was preferred relative to other aromatic solvents. The performance difference between $m$-xylene (entry 5) and $p$-xylene (entry 4 ) suggests that the solvent does indeed play a critical role in organizing the various reaction components. Entries 6 and 7 show that lower catalyst concentration is preferred, in agreement with our concentration studies. Running the reaction at $-20{ }^{\circ} \mathrm{C}$ (entry 8) did not have a significant influence on selectivity. The catalyst was found to be insoluble at lower temperatures. We also investigated the effect of using different amounts of nucleophile on the selectivity (entries 8-10). All three experiments gave similar $k_{\text {rel }}$ values based on \% ee of product 3 .

Finally, we applied our optimized reaction conditions to other substituted para-quinols, in order to understand the influence of substrate structure (Figure 3). Moving the $\mathrm{R}^{1}$

Table 2. Concentration Effects ${ }^{a}$

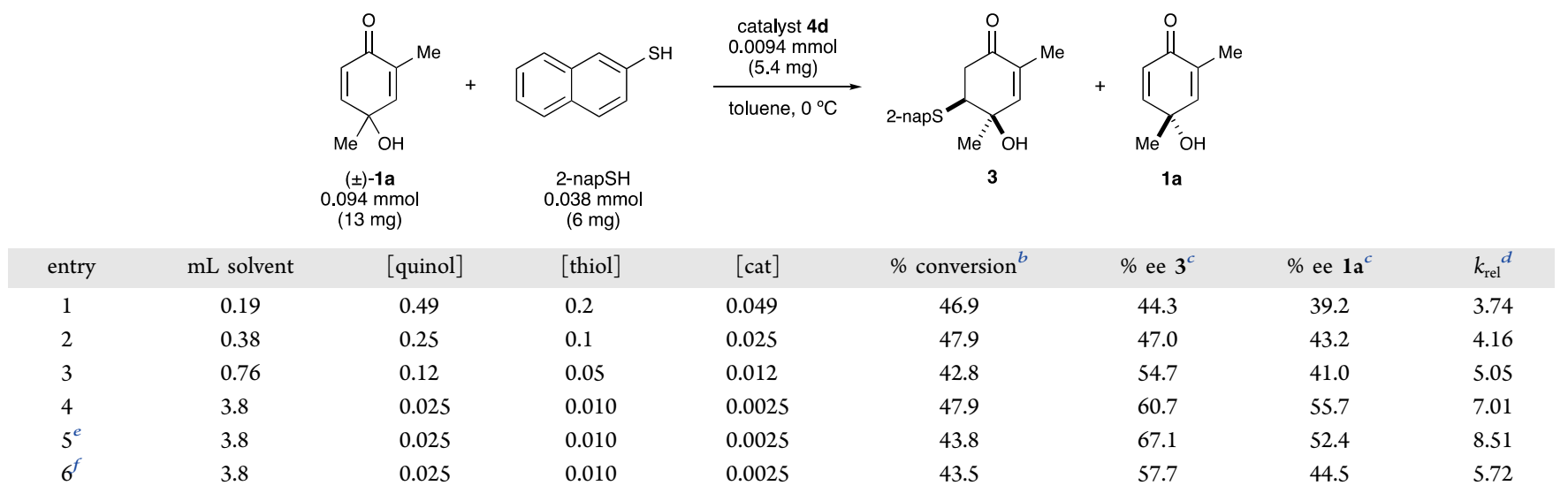

${ }^{a}$ All reactions were performed at $0{ }^{\circ} \mathrm{C}$ unless noted. ${ }^{b}$ Determined using eq 1 . ${ }^{c}$ Determined by chiral HPLC analysis. ${ }^{d}$ Determined using eq 3 . ${ }^{e}$ Reaction performed at $-10{ }^{\circ} \mathrm{C} .{ }^{f}$ Reaction performed at $25{ }^{\circ} \mathrm{C}$. 
Table 3. Examination of Solvent Effects with Bifunctional Thiourea Catalyst ${ }^{a}$

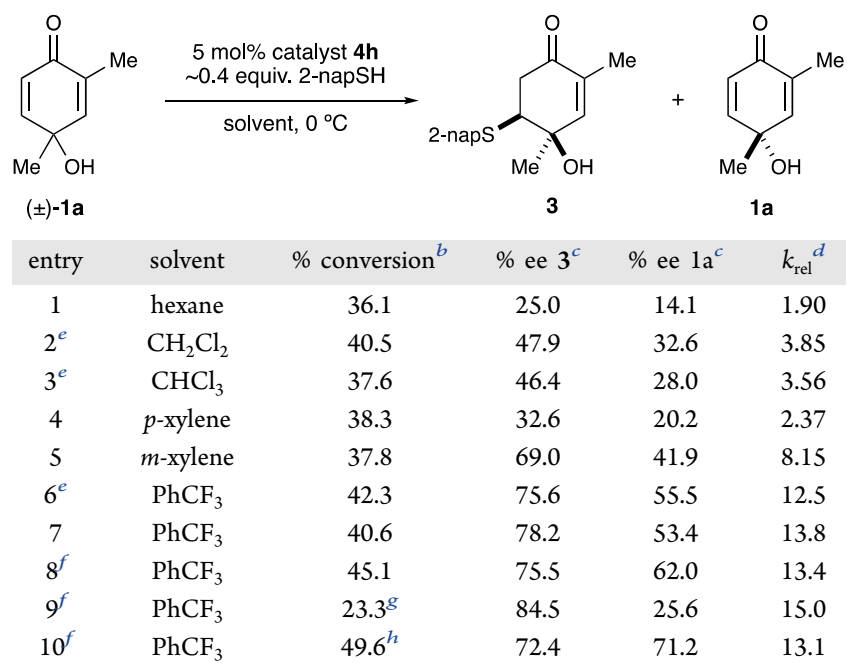

${ }^{a}$ All reactions were performed at $0{ }^{\circ} \mathrm{C}$ with $5 \mathrm{~mol} \%$ catalyst $4 \mathrm{~h}$ unless noted. ${ }^{b}$ Determined using eq $1 .{ }^{c}$ Determined by chiral HPLC analysis. ${ }^{d}$ Determined using eq $3 .{ }^{e} 10 \mathrm{~mol} \%$ catalyst $\mathbf{4 h} .{ }^{f_{\text {Reaction }}}$ performed at $-20^{\circ} \mathrm{C} .{ }^{g} \sim 0.2$ equiv of 2 -napSH used. ${ }^{h} \sim 0.5$ equiv of 2 napSH used.

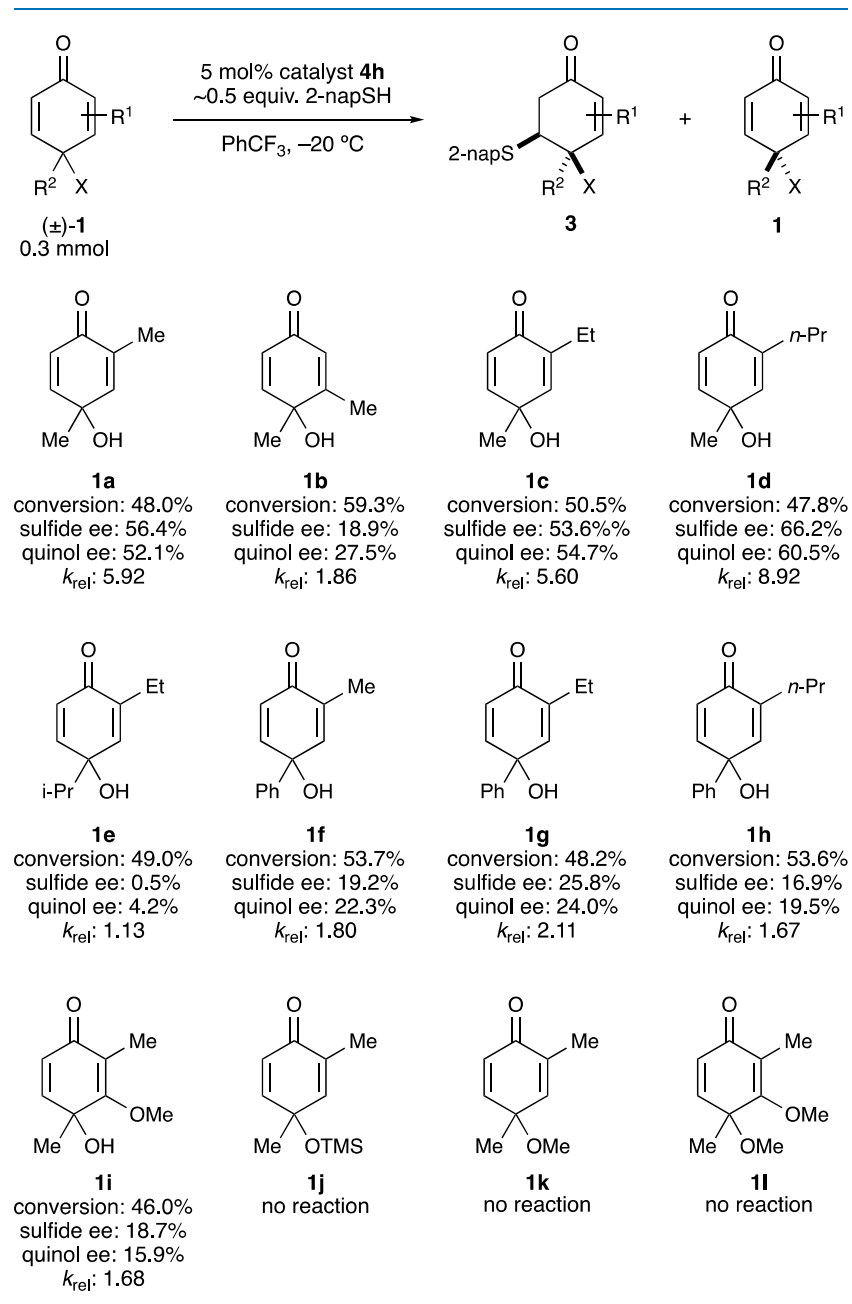

Figure 3. Examining the influence of substrate structure on the kinetic resolution. The conversions were determined using eq 1 . The $k_{\text {rel }}$ values were determined using eq 3 . group in $\mathbf{1}$ to the 3 -position (1b) was detrimental to the selectivity, showing that the 2-position plays a key role in allowing the catalyst to distinguish the enantiomers of the starting material. In contrast, the alkyl chain in the 2-position could be modified (1c, 1d) without affecting the selectivity. Catalyst $4 \mathbf{h}$ does not tolerate $\mathrm{R}^{2}$ groups larger than $\mathrm{CH}_{3}$ (1eh). These groups may hinder the approach of the nucleophile in such a way that rate differences between the two enantiomers become more similar. Adding a methoxy group to the 3-position (1i) was also detrimental. In this case, the carbonyl is a vinylogous ester, which may interact with the hydrogen-bonding components of the catalyst differently than an enone. Finally, the importance of the hydroxyl group was determined with substrates $\mathbf{1} \mathbf{j}-\mathbf{l}$, which all failed to react. These results suggest that, in addition to the aforementioned stereoelectronic effects, ${ }^{22}$ delivery of the thiolate by the hydroxyl $^{25}$ may be a contributing factor. Alternatively, free rotation around the $\mathrm{C} 4-\mathrm{O}$ bond by these larger groups may completely block the approach of the nucleophile from the stereoelectronically preferred trajectory.

Until the absolute configuration of Michael addition product 3 or the unreacted starting material is established, ${ }^{a}$ it will be difficult to develop a complete stereoselectivity model for this resolution. However, two potential models can be proposed (Figure 4) based on our experimental observations. In model
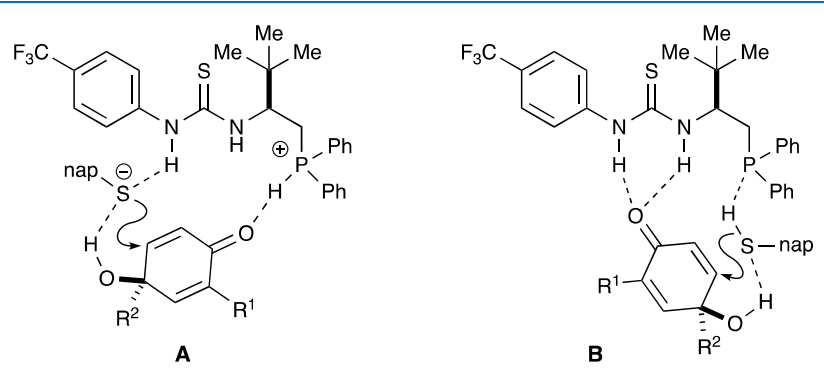

Figure 4. Examining the influence of substrate structure on the kinetic resolution.

A, the phosphine moiety serves as a base to deprotonate the thiol. The quinol substrate can be activated by hydrogen bonding with the phosphonium group. Hydrogen bonds between the thiourea and the quinol hydroxyl group will guide the thiolate to the appropriate alkene for reaction. A similar model has been identified during density functional theory calculations of asymmetric thiol-Michael reactions involving chinchona alkaloid-based ureas. ${ }^{26}$ However, phosphines are much weaker Brønsted bases than amines. ${ }^{27}$ Consequently, complete deprotonation of the thiol by the phosphine is unlikely, though hydrogen bonding with the thiourea would increase the acidity of the thiol. The question of phosphine basicity can be avoided with model $\mathbf{B}$, in which the thiol engages both the phosphine and the hydroxyl group of the quinol in hydrogen bonding. In both cases, binding of the opposite enantiomer of the quinol to the catalyst will introduce steric clashes between the $\mathrm{R}^{1}$ group and the catalyst framework. Both models explain (a) why phosphine oxide $\mathbf{4 j}$ was not a competent catalyst and (b) why substrates $\mathbf{1 j}-\mathbf{1 1}$ were not competent substrates.

\section{CONCLUSIONS}

In conclusion, we have performed regio- and stereoselective thiol-Michael reactions on substituted 2,5-cyclohexadienones. 
These experiments serve as an important proof-of-principle demonstration that kinetic resolutions of 2,5-cyclohexadienonees are possible. We have demonstrated that these reactions can be quite sensitive to substrate effects. Taken as a whole, we believe these results will prove useful for developing more selective kinetic resolutions, with or without cyclohexadienone substrates.

\section{EXPERIMENTAL SECTION}

General Methods. Unless otherwise stated, reactions were performed in flame- or oven-dried glassware under an argon atmosphere using anhydrous solvents. THF, dichloromethane, diethyl ether, toluene, and acetonitrile were dried by passage through a column of activated molecular sieves. Trifluorotoluene was purchased from Acros Organics and used as received. Catalyst $\mathbf{4 b}$ was purchased from Sigma-Aldrich and used as received. Compound $1 \mathbf{k}^{28}$ and catalysts $4 \mathbf{a}^{29} \mathbf{4} \mathbf{c}^{30}$ $\mathbf{4 d},{ }^{31} \mathbf{4 e},^{30} \mathbf{4 f},{ }^{30} \mathbf{4 g},{ }^{32} \mathbf{4 h},{ }^{32} \mathbf{4 l},{ }^{33} \mathbf{4 m},{ }^{34}$ and $\mathbf{4 n}{ }^{35}$ were prepared according to the literature. All other chemicals were purchased from commercial sources and used as received.

Reactions were monitored using thin-layer chromatography (TLC) using glass plates precoated with silica gel XHL w/ UV254 $(250 \mathrm{~mm})$ purchased from SILICYCLE and visualized by UV light or $\mathrm{KMnO}_{4}$, phosphomolybdic acid, or anisaldehyde stains, followed by heating. Silica gel (particle size 32-63 $\mathrm{mm}$ ) purchased from SILICYCLE was used for flash column chromatography.

${ }^{1} \mathrm{H}$ and ${ }^{13} \mathrm{C}$ NMR spectra are reported relative to the residual solvent peak $\left(\delta 7.26\right.$ and $\delta 77.0$ for ${ }^{1} \mathrm{H}$ and ${ }^{13} \mathrm{C}$ in $\mathrm{CDCl}_{3}$, respectively) or tetramethylsilane $\left(\delta 0.00\right.$ for $\left.{ }^{1} \mathrm{H}\right)$ when the residual solvent peak is obscured. Data for ${ }^{1} \mathrm{H}$ NMR spectra are reported as follows: (instrument field strength, solvent) chemical shift $(\delta \mathrm{ppm})$ (multiplicity, coupling constant $(\mathrm{Hz})$, integration). Multiplicity is described using the following abbreviations: $\mathrm{s}=$ singlet, $\mathrm{d}=$ doublet, $\mathrm{t}=$ triplet, $\mathrm{q}=$ quartet, $\mathrm{m}=$ multiplet, $\mathrm{bs}=$ broad singlet, $\mathrm{app}=$ apparent . Data for ${ }^{13} \mathrm{C}$ NMR spectra are reported in terms of chemical shift $(\delta \mathrm{ppm})$. Some reported spectra include minor solvent impurities of water $(\delta 1.56 \mathrm{ppm})$, grease $(\delta 1.26,0.86 \mathrm{ppm})$, and/or silicon grease ( $\delta 0.07 \mathrm{ppm})$, which do not impact product assignments.

Analytical chiral HPLC was performed with an Agilent 1100 Series HPLC equipped with a diode array detector utilizing a Chiralpak IA $(4.6 \times 250 \mathrm{~mm}, 5 \mu \mathrm{m})$, Chiralpak IB $(4.6 \times 250$ $\mathrm{mm}, 5 \mu \mathrm{m})$, Chiralpak IC $(4.6 \times 250 \mathrm{~mm}, 5 \mu \mathrm{m})$, Chiralpak ID $(4.6 \times 250 \mathrm{~mm}, 5 \mu \mathrm{m})$, or Chiralpak IE $(4.6 \times 250 \mathrm{~mm}, 5$ $\mu \mathrm{m})$ column. Visualization was at 254 or $225 \mathrm{~nm}$.

Preparation of Racemic para-Quinols (Method A). The corresponding phenol ( $3 \mathrm{mmol}, 1$ equiv) was dissolved in a mixture of $\mathrm{CH}_{3} \mathrm{CN}$ and $\mathrm{H}_{2} \mathrm{O}(3: 1,30 \mathrm{~mL})$. The solution was then cooled to $0{ }^{\circ} \mathrm{C}$ in an ice bath and (diacetoxyiodo)benzene ( $1.06 \mathrm{~g}$, $3.3 \mathrm{mmol}$, 1.1 equiv) was added slowly. The reaction mixture was then allowed to warm to room temperature, and monitored by TLC. Upon completion of the reaction, saturated $\mathrm{NaHCO}_{3}$ solution was added and the mixture was partially concentrated in vacuo. The aqueous layer was extracted with EtOAc $(3 \times)$. The combined organic layers were dried $\left(\mathrm{Na}_{2} \mathrm{SO}_{4}\right)$, concentrated in vacuo, and purified by silica gel flash column chromatography to afford a desired product.

2-Ethyl-4-hydroxy-4-methylcyclohexa-2,5-dien-1-one (1c). Yellow oil (73\% yield); ${ }^{1} \mathrm{H}$ NMR $\left(400 \mathrm{MHz}, \mathrm{CDCl}_{3}\right): \delta$ $6.84(\mathrm{dd}, J=9.9,3.1 \mathrm{~Hz}, 1 \mathrm{H}), 6.58(\mathrm{dt}, J=3.0,1.5 \mathrm{~Hz}, 1 \mathrm{H})$, $6.12(\mathrm{~d}, J=9.9 \mathrm{~Hz}, 1 \mathrm{H}), 2.31(\mathrm{qd}, J=7.4,1.5 \mathrm{~Hz}, 2 \mathrm{H}), 1.93$ (br s, $1 \mathrm{H}), 1.47(\mathrm{~s}, 3 \mathrm{H}), 1.07(\mathrm{t}, J=7.5 \mathrm{~Hz}, 3 \mathrm{H}) ;{ }^{13} \mathrm{C} \mathrm{NMR}$ $\left(101 \mathrm{MHz}, \mathrm{CDCl}_{3}\right): \delta 185.8,151.8,146.1,138.7,127.1,67.4$, 26.9, 21.7, 12.1; HRMS (ESI $\left.{ }^{-}\right): 151.0759$ calcd for $\mathrm{C}_{9} \mathrm{H}_{11} \mathrm{O}_{2}^{-}$; 151.0755 found.

4-Hydroxy-4-methyl-2-propylcyclohexa-2,5-dien-1-one (1d). Yellow oil (51\% yield); ${ }^{1} \mathrm{H}$ NMR $\left(400 \mathrm{MHz}, \mathrm{CDCl}_{3}\right): \delta$ $6.83(\mathrm{dd}, J=10.0,3.1 \mathrm{~Hz}, 1 \mathrm{H}), 6.59(\mathrm{dt}, J=2.8,1.3 \mathrm{~Hz}, 1 \mathrm{H})$, $6.11(\mathrm{~d}, J=10.0 \mathrm{~Hz}, 1 \mathrm{H}), 2.27-2.21(\mathrm{~m}, 2 \mathrm{H}), 1.90(\mathrm{~s}, 1 \mathrm{H})$, $1.53-1.43$ (q overlap with s, $2 \mathrm{H}), 1.47(\mathrm{~s}, 3 \mathrm{H}), 0.93(\mathrm{t}, J=7.4$ $\mathrm{Hz}, 3 \mathrm{H}) ;{ }^{13} \mathrm{C} \mathrm{NMR}\left(101 \mathrm{MHz}, \mathrm{CDCl}_{3}\right): \delta 185.9,151.8,147.3$, 137.1, 127.1, 67.4, 30.8, 27.0, 21.1, 13.7; HRMS (ESI ${ }^{-}$): 165.0916 calcd for $\mathrm{C}_{10} \mathrm{H}_{13} \mathrm{O}_{2}{ }^{-} ; 165.0912$ found.

2-Ethyl-4-hydroxy-4-isopropylcyclohexa-2,5-dien-1-one (1e). Yellow oil (85\% yield); ${ }^{1} \mathrm{H}$ NMR $\left(400 \mathrm{MHz} \mathrm{CDCl}_{3}\right): \delta$ $6.78(\mathrm{dd}, J=10.1,3.1 \mathrm{~Hz}, 1 \mathrm{H}), 6.52(\mathrm{dt}, J=3.0,1.4 \mathrm{~Hz}, 1 \mathrm{H})$, $6.22(\mathrm{~d}, J=10.1 \mathrm{~Hz}, 1 \mathrm{H}), 2.43-2.23(\mathrm{~m}, 2 \mathrm{H}), 1.99$ (hept, $J=$ $6.9 \mathrm{~Hz}, 1 \mathrm{H}), 1.80(\mathrm{~s}, 1 \mathrm{H}), 108(\mathrm{t}, J=7.4 \mathrm{~Hz}, 3 \mathrm{H}), 0.96(\mathrm{~d}, J=$ $2.2 \mathrm{~Hz}, 3 \mathrm{H}), 0.94(\mathrm{~d}, J=2.3 \mathrm{~Hz}, 3 \mathrm{H}) ;{ }^{13} \mathrm{C} \mathrm{NMR}(101 \mathrm{MHz}$, $\left.\mathrm{CDCl}_{3}\right): \delta 186.2,149.8,144.2,140.7,129.0,72.4,36.8,22.0$, 16.9, 12.4; HRMS $\left(\mathrm{ESI}^{+}\right): 203.1043$ calcd for $\mathrm{C}_{11} \mathrm{H}_{16} \mathrm{~F}_{6} \mathrm{O}_{2} \mathrm{Na}^{+}$; 203.1044 found.

Compounds 4-hydroxy-2,4-dimethylcyclohexa-2,5-dien-1one (1a), ${ }^{36}$ 4-hydroxy-3,4-dimethylcyclohexa-2,5-dien-1-one (1b), ${ }^{36}$ and 4-hydroxy-3-methoxy-2,4-dimethylcyclohexa-2,5dien-1-one $(1 \mathbf{i})^{13 a}$ were prepared by following the same procedure. Their characterization data were in agreement to those previously reported.

Preparation of Racemic para-Quinols (Method B). The 3-ethyl-[1,1'-biphenyl]-4-ol (650 mg, $3.28 \mathrm{mmol}, 1$ equiv) was dissolved in hexamethyldisilazane $(2 \mathrm{~mL})$ and heated at $125{ }^{\circ} \mathrm{C}$ for $30 \mathrm{~min}$ in a microwave reactor. The reaction mixture was concentrated in vacuo. The crude residue $(886.64$ $\mathrm{mg}, 3.28,1$ equiv) was dissolved in a mixture of $\mathrm{CH}_{3} \mathrm{CN}$ and $\mathrm{H}_{2} \mathrm{O}(3: 1)(10 \mathrm{~mL})$ and cooled to $0{ }^{\circ} \mathrm{C}$ in an ice bath. (Diacetoxyiodo)benzene ( $1.16 \mathrm{~g}, 3.61 \mathrm{mmol}, 1.1$ equiv) was added to the reaction slowly. The reaction mixture was allowed to warm to room temperature. The reaction was monitored by TLC. Upon completion of the reaction, saturated $\mathrm{NaHCO}_{3}$ solution was added and the mixture was partially concentrated in vacuo. The aqueous layer was extracted with EtOAc $(3 \times)$. The combined organic layers were then dried over $\left(\mathrm{Na}_{2} \mathrm{SO}_{4}\right)$, concentrated in vacuo, and purified by flash column chromatography to give 3-ethyl-1-hydroxy-[1,1'-biphenyl]$4(1 \mathrm{H})$-one $(1 \mathrm{~g})$ as a yellow oil $(213.5 \mathrm{mg}, 30 \%$ yield after two steps): ${ }^{1} \mathrm{H}$ NMR (400 MHz, $\left.\mathrm{CDCl}_{3}\right): \delta 7.50-7.45(\mathrm{~m}$, $2 \mathrm{H}), 7.41-7.29(\mathrm{~m}, 3 \mathrm{H}), 7.86(\mathrm{dd}, J=9.9,3.1 \mathrm{~Hz}, 1 \mathrm{H}), 6.62$ $(\mathrm{dt}, J=3.2,1.5 \mathrm{~Hz}, 1 \mathrm{H}), 6.22(\mathrm{~d}, J=9.9 \mathrm{~Hz}, 1 \mathrm{H}), 2.36(\mathrm{qd}, J=$ 7.4, $1.5 \mathrm{~Hz}, 2 \mathrm{H}), 2.28$ (d, $J=3.7 \mathrm{~Hz}, 1 \mathrm{H}), 1.08(\mathrm{t}, J=7.4 \mathrm{~Hz}$, $3 \mathrm{H}) ;{ }^{13} \mathrm{C}$ NMR $\left(101 \mathrm{MHz}, \mathrm{CDCl}_{3}\right): \delta 186.6,151.2,145.7$, $139.4,138.0,128.6,127.9,126.3,125.1,71.1,21.7,12.0$; HRMS (ESI ${ }^{-}$): 213.0916 calcd for $\mathrm{C}_{14} \mathrm{H}_{13} \mathrm{O}_{2}^{-} ; 213.0916$ found.

Compounds 1-hydroxy-3-methyl-[1,1'-biphenyl]-4(1H)-one (1f) and 1-hydroxy-3-propylyl-[1,1'-biphenyl $]-4(1 H)$-one (1h) were prepared by following the same procedure. Their characterization data were in agreement with those previously reported. $^{37}$

General Procedure for Preparing Racemic Thiol Addition Products. Dienone ( $0.3 \mathrm{mmol}, 1$ equiv), 2naphthalenethiol (48.1 $\mathrm{mg}, 0.3 \mathrm{mmol}, 1$ equiv), and (-)-cinchonidine ( $4.4 \mathrm{mg}, 0.015 \mathrm{mmol}, 0.05$ equiv) were dissolved in trifluorotoluene $(6 \mathrm{~mL})$ at room temperature. The 
reaction was monitored by TLC. Upon completion of the reaction, the solvent was evaporated in vacuo and the residue purified by flash column chromatography to afford the desired product.

General Procedure for Kinetic Resolution Experiment. Dienone ( $0.3 \mathrm{mmol}, 1$ equiv), 2-naphthalenethiol (24 $\mathrm{mg}, 0.15 \mathrm{mmol}, 0.5$ equiv), and catalyst $4 \mathrm{~h}(7.3 \mathrm{mg}, 0.015$ mmol, 0.05 equiv) were dissolved in trifluorotoluene $(6 \mathrm{~mL})$ at $-20{ }^{\circ} \mathrm{C}$. The reaction was monitored by TLC. Upon completion of the reaction, the solvent was evaporated in vacuo and the residue purified by flash column chromatography to afford the desired product.

4-Hydroxy-2,4-dimethyl-5-(naphthalen-2-ylthio)cyclohex2-en-1-one (3a). Waxy yellow solid (48.4\% isolated yield). The isolated recovery of starting material yield was $19.3 \% .{ }^{1} \mathrm{H}$ NMR (400 MHz, $\left.\mathrm{CDCl}_{3}\right): \delta 7.96(\mathrm{~d}, J=1.9 \mathrm{~Hz}, 1 \mathrm{H}), 7.85-$ $7.73(\mathrm{~m}, 3 \mathrm{H}), 7.53-7.47(\mathrm{~m}, 3 \mathrm{H}), 6.55(\mathrm{t}, J=1.2 \mathrm{~Hz}, 1 \mathrm{H})$, 3.71 (ddd, $J=8.0,4.3,1.0 \mathrm{~Hz}, 1 \mathrm{H}$ ), 3.06-2.97 (dd overlap with s, $J=17.0,8.0 \mathrm{~Hz}, 1 \mathrm{H}), 2.99(\mathrm{~s}, 1 \mathrm{H}), 2.89$ (dd, $J=16.9$, $4.3 \mathrm{~Hz}, 1 \mathrm{H}), 1.79$ (d, $J=1.4 \mathrm{~Hz}, 3 \mathrm{H}), 1.58(\mathrm{~s}, 3 \mathrm{H}) ;{ }^{13} \mathrm{C} \mathrm{NMR}$ $\left(101 \mathrm{MHz}, \mathrm{CDCl}_{3}\right): \delta 196.7,148.4,135.3,133.6,132.5,131.8$, 131.2, 129.6, 129.1, 127.7, 127.4, 126.8, 126.6, 70.3, 58.5, 42.2, 27.2, 15.5; HRMS $\left(\mathrm{ESI}^{+}\right): 321.0925$ calcd for $\mathrm{C}_{18} \mathrm{H}_{18} \mathrm{O}_{2} \mathrm{SNa}^{+}$; 321.0919 found.

4-Hydroxy-3,4-dimethyl-5-(naphthalene-2-ylthio)cyclohex-2-en-1-one (3b). White solid (51.0\% isolated yield). The isolated recovery of starting material yield was $32.0 \% \mathrm{mp}$ $105-107{ }^{\circ} \mathrm{C} ;{ }^{1} \mathrm{H}$ NMR $\left(400 \mathrm{MHz}, \mathrm{CDCl}_{3}\right): \delta 7.99-7.96(\mathrm{~m}$, $1 \mathrm{H}), 7.80(\mathrm{dt}, J=8.6,6.7 \mathrm{~Hz}, 3 \mathrm{H}), 7.57-7.43(\mathrm{~m}, 3 \mathrm{H}), 5.88$ (s, $1 \mathrm{H}), 3.72(\mathrm{t}, J=4.0 \mathrm{~Hz}, 1 \mathrm{H}), 3.43(\mathrm{~s}, 1 \mathrm{H}), 3.05-2.93$ (ddd overlap with ddd, $J=17.6,3.9,0.8 \mathrm{~Hz}, 1 \mathrm{H}), 2.99$ (ddd, $J=$ $18.2,3.9,0.7 \mathrm{~Hz}, 1 \mathrm{H}$ ), 2.08 (d, $J=1.3 \mathrm{~Hz}, 3 \mathrm{H}$ ), 1.61 (d, $J=0.9$ $\mathrm{Hz}, 3 \mathrm{H}) ;{ }^{13} \mathrm{C}$ NMR (101 MHz, $\left.\mathrm{CDCl}_{3}\right): \delta 195.1,165.1,133.6$, $132.6,132.0,131.0,129.7,129.2,127.7,127.5,126.9,126.8$, 126.6, 72.4, 61.6, 43.0, 25.2, 19.1; HRMS $\left(\mathrm{ESI}^{+}\right): 321.0925$ calcd for $\mathrm{C}_{18} \mathrm{H}_{18} \mathrm{O}_{2} \mathrm{SNa}^{+} ; 321.0922$ found.

2-Ethyl-4-hydroxy-4-methyl-5-(naphthalen-2-ylthio)cyclohex-2-en-1-one (3c). Yellow oil (45.2\% isolated yield). The isolated recovery of starting material yield was $34.7 \% .{ }^{1} \mathrm{H}$ NMR (400 MHz, $\left.\mathrm{CDCl}_{3}\right): \delta 7.96(\mathrm{~d}, J=1.7 \mathrm{~Hz}, 1 \mathrm{H}), 7.84-$ $7.75(\mathrm{~m}, 3 \mathrm{H}), 7.55-7.46(\mathrm{~m}, 3 \mathrm{H}), 6.49(\mathrm{~d}, J=1.4 \mathrm{~Hz}, 1 \mathrm{H})$, 3.71 (ddd, $J=7.9,4.3,1.0 \mathrm{~Hz}, 1 \mathrm{H}), 3.05(\mathrm{~s}, 1 \mathrm{H}), 3.01(\mathrm{dd}, J=$ $16.9,7.9 \mathrm{~Hz}, 1 \mathrm{H}), 2.89$ (dd, $J=17.0,4.3 \mathrm{~Hz}, 1 \mathrm{H}), 2.23$ (qt, $J=$ 7.4, $1.5 \mathrm{~Hz}, 2 \mathrm{H}), 1.60(\mathrm{~s}, 3 \mathrm{H}), 1.04(\mathrm{t}, J=7.5 \mathrm{~Hz}, 3 \mathrm{H}) ;{ }^{13} \mathrm{C}$ NMR $\left(101 \mathrm{MHz}, \mathrm{CDCl}_{3}\right): \delta 196.5,146.8,140.4,133.5,132.4$, $131.5,131.3,129.5,129.0,127.6,127.4,126.7,126.5,70.2$, 58.1, 42.4, 27.2, 21.7, 12.2; HRMS (ESI $\left.{ }^{+}\right): 335.1082$ calcd for $\mathrm{C}_{19} \mathrm{H}_{20} \mathrm{O}_{2} \mathrm{SNa}^{+} ; 335.1077$ found.

4-Hydroxy-4-methyl-5-(naphthalen-2-ylthio)-2-propylcyclohex-2-en-1-one (3d). Yellow oil (51\% isolated yield). The isolated recovery of starting material yield was $30 \% .{ }^{1} \mathrm{H}$ NMR $\left(400 \mathrm{MHz}, \mathrm{CDCl}_{3}\right): \delta 7.96(\mathrm{~d}, J=1.5 \mathrm{~Hz}, 1 \mathrm{H}), 7.85-7.76(\mathrm{~m}$, $3 \mathrm{H}), 7.55-7.46(\mathrm{~m}, 3 \mathrm{H}), 6.50(\mathrm{~d}, J=1.3 \mathrm{~Hz}, 1 \mathrm{H}), 3.71$ (ddd $J$ $=7.5,4.2,1.1 \mathrm{~Hz}, 1 \mathrm{H}), 3.06(\mathrm{~s}, 1 \mathrm{H}), 3.01(\mathrm{dd}, J=17.0,7.5 \mathrm{~Hz}$, $1 \mathrm{H}), 2.89$ (dd, $J=17,4.3 \mathrm{~Hz}, 1 \mathrm{H}), 2.29-2.07(\mathrm{~m}, 2 \mathrm{H}), 1.59$ (s, $3 \mathrm{H}), 1.45$ (sex, $J=7.4 \mathrm{~Hz}, 2 \mathrm{H}), 0.92(\mathrm{t}, J=7.3 \mathrm{~Hz}, 3 \mathrm{H})$; ${ }^{13} \mathrm{C}$ NMR $\left(101 \mathrm{MHz}, \mathrm{CDCl}_{3}\right): \delta 196.3,148.0,139.0,133.6$, $132.5,131.6,131.3,129.6,129.0,127.7,127.4,126.8,126.6$, 70.3, 58.6, 42.5, 30.8, 27.1, 21.2, 13.7; HRMS (ESI $\left.{ }^{+}\right) 349.1238$ calcd for $\mathrm{C}_{20} \mathrm{H}_{22} \mathrm{O}_{2} \mathrm{SNa}^{+}$; 349.1233 found.

2-Ethyl-4-hydroxy-4-isopropyl-5-(naphthalen-2-ylthio)cyclohex-2-en-1-one (3e). Waxy yellow solid (35\% isolated yield). The isolated recovery of starting material yield was $35 \%$.
${ }^{1} \mathrm{H}$ NMR $\left(400 \mathrm{MHz}, \mathrm{CDCl}_{3}\right): \delta 7.96(\mathrm{~d}, J=1.5 \mathrm{~Hz}, 1 \mathrm{H})$, $7.85-7.75(\mathrm{~m}, 3 \mathrm{H}), 7.54-7.46(\mathrm{~m}, 3 \mathrm{H}), 6.60(\mathrm{~d}, J=1.4 \mathrm{~Hz}$, $1 \mathrm{H}), 3.89$ (ddd, $J=6.9,4.2,1.3 \mathrm{~Hz}, 1 \mathrm{H}), 3.02$ (dd overlap with s, $J=17.3,6.8 \mathrm{~Hz}, 1 \mathrm{H}), 2.98(\mathrm{~s}, 1 \mathrm{H}), 2.88(\mathrm{dd}, J=17.2,4.2$ $\mathrm{Hz}, 1 \mathrm{H}$ ), 2.28 (sep overlap with dd, $J=6.8 \mathrm{~Hz}, 1 \mathrm{H}$ ), 2.24 (dd, $J=7.48,1.4 \mathrm{~Hz}, 2 \mathrm{H}), 1.12(\mathrm{~d}, J=6.8 \mathrm{~Hz}, 3 \mathrm{H}), 1.05(\mathrm{t}, J=7.4$ $\mathrm{Hz}, 3 \mathrm{H}), 0.98$ (d, $J=6.8 \mathrm{~Hz}, 3 \mathrm{H}) ;{ }^{13} \mathrm{C} \mathrm{NMR}(101 \mathrm{MHz}$, $\left.\mathrm{CDCl}_{3}\right): \delta 196.2,145.7,141.4,133.5,132.5,131.9,131.4$, $129.7,129.0,127.7,127.5,126.8,126.6,74.0,56.3,42.2,34.9$, 22.1, 17.8, 16.6, 12.5; HRMS $\left(\mathrm{ESI}^{+}\right): 363.1395$ calcd for $\mathrm{C}_{21} \mathrm{H}_{24} \mathrm{O}_{2} \mathrm{SNa}^{+} ; 363.1389$ found.

1-Hydroxy-5-methyl-2-(naphthalen-2-ylthio)-2,3-dihydro$\left[1,1^{\prime}\right.$-biphenyl]-4(1H)-one (3f). Yellow foam (52\% isolated yield). The isolated recovery of starting material yield was $38 \%$. ${ }^{1} \mathrm{H}$ NMR (400 MHz, $\mathrm{CDCl}_{3}$ ): $\delta 7.79-7.76(\mathrm{~m}, 1 \mathrm{H}), 7.74(\mathrm{~d}, J$ $=1.9 \mathrm{~Hz}, 1 \mathrm{H}), 7.71(\mathrm{dd}, J=9.1,2.7 \mathrm{~Hz}, 2 \mathrm{H}), 7.49-7.45(\mathrm{~m}$, $4 \mathrm{H}), 7.35$ (dd, $J=8.7,1.9 \mathrm{~Hz}, 2 \mathrm{H}), 7.32-7.29$ (m, 2H), 7.25$7.23(\mathrm{~m}, 1 \mathrm{H}), 6.63(\mathrm{t}, J=0.8 \mathrm{~Hz}, 1 \mathrm{H}), 3.92(\mathrm{ddd}, J=7.8,4.1$, $1.1 \mathrm{~Hz}, 1 \mathrm{H}), 3.72(\mathrm{~s}, 1 \mathrm{H}), 2.97$ (dd, $J=16.8,7.8 \mathrm{~Hz}, 1 \mathrm{H}), 2.79$ (dd, $J=16.8,4.1 \mathrm{~Hz}, 1 \mathrm{H}), 1.91(\mathrm{~d}, J=1.5 \mathrm{~Hz}, 3 \mathrm{H}) ;{ }^{13} \mathrm{C} \mathrm{NMR}$ $\left(101 \mathrm{MHz}, \mathrm{CDCl}_{3}\right): \delta 196.9,146.3,142.1,136.6,133.4,132.4$, $132.3,130.7,129.8,128.8,128.4,128.1,127.6,127.5,126.6$, 126.6, 126.0, 74.4, 60.3, 41.9, 15.5; HRMS $\left(\mathrm{ESI}^{-}\right): 359.1106$ calcd for $\mathrm{C}_{23} \mathrm{H}_{19} \mathrm{O}_{2} \mathrm{~S}^{-} ; 359.1104$ found.

5-Ethyl-1-hydroxy-2-(naphthalen-2-ylthio)-2,3-dihydro$\left[1,1^{\prime}\right.$-biphenyl]-4(1H)-one (3g). Light yellow foam (46\% isolated yield). The isolated recovery of starting material yield was $47 \% .{ }^{1} \mathrm{H}$ NMR $\left(400 \mathrm{MHz}, \mathrm{CDCl}_{3}\right): \delta 7.79-7.74(\mathrm{~m}$, $2 \mathrm{H}), 7.72-7.67(\mathrm{~m}, 2 \mathrm{H}), 7.51-7.45(\mathrm{~m}, 4 \mathrm{H}), 7.38-7.31(\mathrm{~m}$, $3 \mathrm{H}), 7.31-7.27(\mathrm{~m}, 1 \mathrm{H}), 7.26-7.23(\mathrm{~m}, 1 \mathrm{H}), 6.57(\mathrm{q}, J=1.3$ $\mathrm{Hz}, 1 \mathrm{H}), 3.91$ (ddd, $J=7.6,4.1,1.2 \mathrm{~Hz}, 1 \mathrm{H}), 3.76(\mathrm{~s}, 1 \mathrm{H})$, $2.97(\mathrm{dd}, J=16.8,7.6 \mathrm{~Hz}, 1 \mathrm{H}), 2.78(\mathrm{dd}, J=16.8,4.1 \mathrm{~Hz}$, $1 \mathrm{H}), 2.35$ (qdd, $J=7.3,3.3,1.4 \mathrm{~Hz}, 1 \mathrm{H}), 1.11(\mathrm{t}, J=7.4 \mathrm{~Hz}$, $3 \mathrm{H}) ;{ }^{13} \mathrm{C}$ NMR $\left(101 \mathrm{MHz}, \mathrm{CDCl}_{3}\right): \delta 196.5,144.8,142.2$, $141.9,133.4,132.4,132.2,130.8,129.8,128.8,128.4,128.1$, 127.6, 127.4, 126.6, 126.6, 126.0, 74.4, 60.3, 42.2, 21.9, 12.4; HRMS $\left(\right.$ ESI $\left.^{+}\right): 397.1238$ calcd for $\mathrm{C}_{24} \mathrm{H}_{22} \mathrm{O}_{2} \mathrm{SNa}^{+}$; 397.1232 found.

1-Hydroxy-2-(naphthalen-2-ylthio)-5-propyl-2,3-dihydro$\left[1,1^{\prime}\right.$-biphenyl]-4(1H)-one (3h). Yellow oil $(41.1 \%$ isolated yield). The isolated recovery of starting material yield was 41.1\%. ${ }^{1} \mathrm{H}$ NMR (400 MHz, $\left.\mathrm{CDCl}_{3}\right): \delta 7.81-7.73(\mathrm{~m}, 2 \mathrm{H})$, $7.73-7.67(\mathrm{~m}, 2 \mathrm{H}), 7.52-7.43(\mathrm{~m}, 4 \mathrm{H}), 7.39-7.31(\mathrm{~m}, 2 \mathrm{H})$, $7.29(\mathrm{dt}, J=12.2,1.4 \mathrm{~Hz}, 2 \mathrm{H}), 7.26-7.23(\mathrm{~m}, 1 \mathrm{H}), 6.58(\mathrm{q}, J$ $=1.2 \mathrm{~Hz}, 1 \mathrm{H}), 3.90(\mathrm{ddd}, J=7.4,4.0,1.3 \mathrm{~Hz}, 1 \mathrm{H}), 3.78(\mathrm{~s}$, $1 \mathrm{H}), 2.96(\mathrm{dd}, J=16.8,7.4 \mathrm{~Hz}, 1 \mathrm{H}), 2.77(\mathrm{dd}, J=16.8,4.0$ $\mathrm{Hz}, 1 \mathrm{H}), 2.29(\mathrm{tdd}, J=7.3,4.0,1.3 \mathrm{~Hz}, 2 \mathrm{H}), 1.53(\mathrm{t}, J=7.6$ $\mathrm{Hz}, 2 \mathrm{H}), 0.97(\mathrm{t}, J=7.4 \mathrm{~Hz}, 3 \mathrm{H}) ;{ }^{13} \mathrm{C}$ NMR $(101 \mathrm{MHz}$, $\left.\mathrm{CDCl}_{3}\right): \delta 196.5,145.8,142.1,140.5,133.4,132.5,132.2$, $130.8,129.8,128.8,128.5,128.2,127.6,127.5,126.6,126.6$, 126.1, 74.5, 60.6, 42.2, 30.9, 21.5, 13.9; HRMS (ESI ${ }^{-}$): 387.1419 calcd for $\mathrm{C}_{25} \mathrm{H}_{23} \mathrm{O}_{2} \mathrm{~S}^{-} ; 387.1417$ found.

4-Hydroxy-3-methoxy-2,4-dimethyl-5-(naphthalen-2ylthio)cyclohex-2-en-1-one (3i). Waxy yellow solid (44\% isolated yield). The isolated recovery of starting material yield was $48 \%$. ${ }^{1} \mathrm{H}$ NMR $\left(400 \mathrm{MHz}, \mathrm{CDCl}_{3}\right): \delta 7.95(\mathrm{~d}, J=1.9 \mathrm{~Hz}$, $1 \mathrm{H}), 7.84-7.75(\mathrm{~m}, 3 \mathrm{H}), 7.50(\mathrm{ddd}, J=9.4,5.0,2.0 \mathrm{~Hz}, 3 \mathrm{H})$, $4.02(\mathrm{t}, J=0.8 \mathrm{~Hz}, 3 \mathrm{H}), 3.66(\mathrm{dd}, J=7.0,4.2 \mathrm{~Hz}, 1 \mathrm{H}), 3.14(\mathrm{~s}$, $1 \mathrm{H}), 2.97(\mathrm{dd}, J=17.0,7.0 \mathrm{~Hz}, 1 \mathrm{H}), 2.86(\mathrm{dd}, J=17.0,4.2$ $\mathrm{Hz}, 1 \mathrm{H}), 1.80(\mathrm{~s}, 1 \mathrm{H}), 1.67(\mathrm{~s}, 1 \mathrm{H}) ;{ }^{13} \mathrm{C}$ NMR (101 MHz, $\left.\mathrm{CDCl}_{3}\right): \delta 196.3,171.9,133.6,132.6,132.0,131.2,129.7$, $129.0,127.7,127.5,126.8,126.6,119.2$, 73.2, 61.3, 57.6, 41.7, 
25.4, 9.2; $\mathrm{HRMS}\left(\mathrm{ESI}^{+}\right): 351.1031$ calcd for $\mathrm{C}_{19} \mathrm{H}_{20} \mathrm{O}_{3} \mathrm{SNa}^{+}$; 351.1027 found.

\section{ASSOCIATED CONTENT}

\section{S Supporting Information}

The Supporting Information is available free of charge on the ACS Publications website at DOI: 10.1021/acsomega.8b01787.

Additional experimental procedures, compound characterization data, HPLC traces, and copies of NMR spectra (PDF)

\section{AUTHOR INFORMATION}

\section{Corresponding Author}

*E-mail: andrew.harned@ttu.edu. Phone: (806)-834-6755.

\section{ORCID}

Andrew. M. Harned: 0000-0002-6782-6224

\section{Present Addresses}

${ }^{\S}$ Milliken \& Company, Spartanburg, SC 29303, United States.

${ }^{\text {II }}$ College of Pharmacy, University of Utah, Salt Lake City, UT 84112, United States.

\section{Author Contributions}

T.T., N.G.M., and L.M. performed the experimental work. A.M.H. oversaw the scientific direction of the project. T.T., N.G.M., and A.M.H. contributed to writing the article. All authors have given approval to the final version of the article.

Notes

The authors declare no competing financial interest.

\section{ACKNOWLEDGMENTS}

Financial support for this work provided by Texas Tech University and the National Science Foundation (CHE1541685). NMR data were collected using instruments supported by the NSF CRIF Program (CHE-1048553).

\section{ADDITIONAL NOTE}

${ }^{a}$ The absolute configuration of the products has not been determined. The indicated stereochemistry is meant to show the relative configuration of the Michael addition product.

\section{REFERENCES}

(1) Roche, S. P.; Porco, J. A., Jr. Dearomatization Strategies in the Synthesis of Complex Natural Products. Angew. Chem., Int. Ed. 2011, 50, 4068-4093.

(2) Selected recent examples: (a) Konkol, L. C.; Guo, F.; Sarjeant, A. A.; Thomson, R. J. Enantioselective Total Synthesis and Studies into the Configurational Stability of Bismurrayaquinone A. Angew. Chem., Int. Ed. 2011, 50, 9931-9934. (b) Kobayakawa, Y.; Nakada, M. Total Syntheses of (-)-Scabronines G and A, and (-)-Episcabronine A. Angew. Chem., Int. Ed. 2013, 52, 7569-7573. (c) Li, H.; Zhang, Y.; Xie, X.; Ma, H.; Zhao, C.; Zhao, G.; She, X. Bioinspired Total Synthesis of Gymnothelignan N. Org. Lett. 2014, 16, 44404443. (d) Rycek, L.; Hayward, J. J.; Latif, M. A.; Tanko, J.; Simionescu, R.; Hudlicky, T. Chemoenzymatic Total Synthesis of Hydromorphone by an Oxidative Dearomatization/Intramolecular [4 + 2] Cycloaddition Sequence: A Second-Generation Approach. J. Org. Chem. 2016, 81, 10930-10941. (e) Hayashi, T.; Ohmori, K.; Suzuki, K. Synthetic Study on Carthamin. 2. Stereoselective Approach to CGlycosyl Quinochalcone via Desymmetrization. Org. Lett. 2017, 19, 866-869. (f) Smith, B. R.; Njardarson, J. T. Double-Diels-Alder Approach to Maoecrystal V. Unexpected C-C Bond-Forming Fragmentations of the [2.2.2]-Bicyclic Core. Org. Lett. 2017, 19, 5316-5319. (g) Leung, J. C.; Bedermann, A. A.; Njardarson, J. T.;
Spiegel, D. A.; Murphy, G. K.; Hama, N.; Twenter, B. M.; Dong, P.; Shirahata, T.; McDonald, I. M.; Inoue, M.; Taniguchi, N.; McMahon, T. C.; Schneider, C. M.; Tao, N.; Stoltz, B. M.; Wood, J. L. Total Synthesis of ( \pm )-Phomoidride D. Angew. Chem., Int. Ed. 2018, 57, 1991-1994. (h) Smith, B. R.; Njardarson, J. T. [2.2.2]- to [3.2.1]Bicycle Skeletal Rearrangement Approach to the Gibberellin Family of Natural Products. Org. Lett. 2018, 20, 2993-2996.

(3) (a) Wells, G.; Berry, J. M.; Bradshaw, T. D.; Burger, A. M.; Seaton, A.; Wang, B.; Westwell, A. D.; Stevens, M. F. G. 4-Substituted 4-Hydroxycyclohexa-2,5-dien-1-ones with Selective Activities against Colon and Renal Cancer Cell Lines. J. Med. Chem. 2003, 46, 532541. (b) Berry, J. M.; Bradshaw, T. D.; Fichtner, I.; Ren, R.; Schwalbe, C. H.; Wells, G.; Chew, E.-H.; Stevens, M. F. G.; Westwell, A. D. Quinols as Novel Therapeutic Agents. 2.14-(1-Arylsulfonylindol-2yl)-4-hydroxycyclohexa-2,5-dien-1-ones and Related Agents as Potent and Selective Antitumor Agents. J. Med. Chem. 2005, 48, 639-644. (c) McCarroll, A. J.; Bradshaw, T. D.; Westwell, A. D.; Matthews, C. S.; Stevens, M. F. G. Quinols As Novel Therapeutic Agents. 7.1Synthesis of Antitumor 4-[1-(Arylsulfonyl-1H-indol-2-yl)]-4-hydroxycyclohexa-2,5-dien-1-ones by Sonogashira Reactions. J. Med. Chem. 2007, 50, 1707-1710. (d) Dong, S.; Cahill, K. J.; Kang, M.-I.; Colburn, N. H.; Henrich, C. J.; Wilson, J. A.; Beutler, J. A.; Johnson, R. P.; Porco, J. A., Jr. Microwave-Based Reaction Screening: Tandem Retro-Diels-Alder/Diels-Alder Cycloadditions ofo-Quinol Dimers. J. Org. Chem. 2011, 76, 8944-8954. (e) Hexum, J. K.; Tello-Aburto, R.; Struntz, N. B.; Harned, A. M.; Harki, D. A. Bicyclic Cyclohexenones as Inhibitors of NF- $\kappa$ B Signaling. ACS Med. Chem. Lett. 2012, 3, 459464.

(4) Kalstabakken, K. A.; Harned, A. M. Asymmetric transformations of achiral 2,5-cyclohexadienones. Tetrahedron 2014, 70, 9571-9585.

(5) Recent results: (a) Han, Y.; Breitler, S.; Zheng, S.-L.; Corey, E. J. Enantioselective Conversion of Achiral Cyclohexadienones to Chiral Cyclohexenones by Desymmetrization. Org. Lett. 2016, 18, 61726175. (b) Yao, W.; Dou, X.; Wen, S.; Wu, J.; Vittal, J. J.; Lu, Y. Enantioselective desymmetrization of cyclohexadienones via an intramolecular Rauhut-Currier reaction of allenoates. Nat. Commun. 2016, 7, 13024. (c) Naganawa, Y.; Kawagishi, M.; Ito, J.-i.; Nishiyama, $\mathrm{H}$. Asymmetric Induction at Remote Quaternary Centers of Cyclohexadienones by Rhodium-Catalyzed Conjugate Hydrosilylation. Angew. Chem., Int. Ed. 2016, 55, 6873-6876. (d) Kumar, R.; Hoshimoto, Y.; Tamai, E.; Ohashi, M.; Ogoshi, S. Two-step synthesis of chiral fused tricyclic scaffolds from phenols via desymmetrization on nickel. Nat. Commun. 2017, 8, 32. (e) Reddy Anugu, R.; Chegondi, R. Tunable Diastereoselective Desymmetrization of Cyclohexadienones Triggered by Copper-Catalyzed Three-Component Coupling Reaction. J. Org. Chem. 2017, 82, 6786-6794. (f) Wu, W.; Chen, T.; Chen, J.; Han, X. Cationic Palladium(II)-Catalyzed Reductive Cyclization of Alkynyl Cyclohexadienones. J. Org. Chem. 2018, 83, 1033-1040. (g) Gollapelli, K. K.; Donikela, S.; Manjula, N.; Chegondi, R. Rhodium-Catalyzed Highly Regio- and Enantioselective Reductive Cyclization of Alkyne-Tethered Cyclohexadienones. ACS Catal. 2018, 8, 1440-1447.

(6) Reviews: (a) Parra, A.; Reboredo, S. Chiral Hypervalent Iodine Reagents: Synthesis and Reactivity. Chem.-Eur. J. 2013, 19, 1724417260. (b) Singh, F. V.; Wirth, T. Hypervalent Iodine-Catalyzed Oxidative Functionalizations Including Stereoselective Reactions. Chem.-Asian J. 2014, 9, 950-971. (c) Berthiol, F. Reagent and Catalyst Design for Asymmetric Hypervalent Iodine Oxidations. Synthesis 2015, 47, 587-603.

(7) (a) Murray, S. J.; Ibrahim, H. Asymmetric Kita spirolactonisation catalysed by anti-dimethanoanthracene-based iodoarenes. Chem. Commun. 2015, 51, 2376-2379. (b) Zhang, D.-Y.; Xu, L.; Wu, H.; Gong, L.-Z. Chiral Iodine-Catalyzed Dearomatizative Spirocyclization for the Enantioselective Construction of an All-Carbon Stereogenic Center. Chem.-Eur. J. 2015, 21, 10314-10317. (c) Coffinier, R.; El Assal, M.; Peixoto, P. A.; Bosset, C.; Miqueu, K.; Sotiropoulos, J.-M.; Pouységu, L.; Quideau, S. Total Synthesis of (-)-Bacchopetiolone via an Asymmetric Hydroxylative Phenol Dearomatization/[4+2]-Dimerization Cascade Promoted by a Novel Salen-Type Chiral Iodane. 
Org. Lett. 2016, 18, 1120-1123. (d) Antien, K.; Viault, G.; Pouységu, L.; Peixoto, P. A.; Quideau, S. Asymetric dearomative spirolactonization of naphthols using $\lambda^{3}$-iodanes under chiral phase-transfer catalysis. Tetrahedron 2017, 73, 3684-3690. (e) Ogasawara, M.; Sasa, H.; Hu, H.; Amano, Y.; Nakajima, H.; Takenaga, N.; Nakajima, K.; Kita, Y.; Takahashi, T.; Dohi, T. Atropisomeric Chiral Diiododienes (Z,Z)-2,3-Di(1-iodoalkylidene)tetralins: Synthesis, Enantiomeric Resolution, and Application in Asymmetric Catalysis. Org. Lett. 2017, 19, 4102-4105. (f) Zhang, Y.; Liao, Y.; Liu, X.; Xu, X.; Lin, L.; Feng, X. Catalytic asymmetric hydroxylative dearomatization of 2-naphthols: synthesis of lacinilene derivatives. Chem. Sci. 2017, 8, 6645-6649.

(8) For biocatalytic enantioselective oxidative dearomatizations, see: Baker Dockrey, S. A.; Lukowski, A. L.; Becker, M. R.; Narayan, A. R. $\mathrm{H}$. Biocatalytic site- and enantioselective oxidative dearomatization of phenols. Nat. Chem. 2017, 10, 119-125.

(9) Harned, A. M. Asymmetric oxidative dearomatizations promoted by hypervalent iodine(III) reagents: an opportunity for rational catalyst design? Tetrahedron Lett. 2014, 55, 4681-4689.

(10) (a) Harned, A. M. Concerning the Mechanism of Iodine(III)Mediated Oxidative Dearomatization of Phenols. Org. Biomol. Chem. 2018, 16, 2324-2329. (b) Tang, T.; Harned, A. M. Experimental evidence for the formation of cationic intermediates during iodine(III)-mediated oxidative dearomatization of phenols. Org. Biomol. Chem. 2018, 16, 6871-6874.

(11) (a) Volp, K. A.; Harned, A. M. Chiral Aryl Iodide Catalysts for the Enantioselective Synthesis of para-Quinols. Chem. Commun. 2013, 49, 3001-3003. (b) Uyanik, M.; Sasakura, N.; Mizuno, M.; Ishihara, K. Enantioselective Synthesis of Masked Benzoquinones Using Designer Chiral Hypervalent Organoiodine(III) Catalysis. ACS Catal. 2017, 7, 872-876. (c) Muñiz, K.; Fra, L. Enantioselective 4Hydroxylation of Phenols under Chiral Organoiodine(I/III) Catalysis. Synthesis 2017, 49, 2901-2906.

(12) (a) Li, J.; Liu, G.-L.; Zhao, X.-H.; Du, J.-Y.; Qu, H.; Chu, W.D.; Ding, M.; Jin, C.-Y.; Wei, M.-X.; Fan, C.-A. Formal Synthesis of (士)-Morphine. Chem.-Asian J. 2013, 8, 1105-1109. (b) He, C.; Zhu, C.; Dai, Z.; Tseng, C.-C.; Ding, H. Divergent total Synthesis of Indoxamycins A, C, and F. Angew. Chem., Int. Ed. 2013, 52, 1325613260. (c) Du, J.-Y.; Zeng, C.; Han, X.-J.; Qu, H.; Zhao, X.-H.; An, X.-T.; Fan, C.-A. Asymmetric total Synthesis of Apocynaceae Hydrocarbazole Alkaloids (+)-Deethylibophyllidine and (+)-Limaspermidine. J. Am. Chem. Soc. 2015, 137, 4267-4273.

(13) (a) Volp, K. A.; Johnson, D. M.; Harned, A. M. A Concise Synthetic Approach to the Sorbicillactones: Total Synthesis of Sorbicillactone A and 9-epi-Sorbicillactone A. Org. Lett. 2011, 13, 4486-4489. (b) Moon, N. G.; Harned, A. M. A Concise Synthetic Route to the Stereotetrad Core of the Briarane Diterpenoids. Org. Lett. 2015, 17, 2218-2221. (c) Sib, A.; Gulder, T. A. M. Stereoselective Total Synthesis of Bisorbicillinoid Natural Products by Enzymatic Oxidative Dearomatization/Dimerization. Angew. Chem., Int. Ed. 2017, 56, 12888-12891.

(14) Chauhan, P.; Mahajan, S.; Enders, D. Organocatalytic CarbonSulfur Bond-Forming Reactions. Chem. Rev. 2014, 114, 8807-8864.

(15) For desymmetrization of achiral cyclohexadienones via thiolMichael reaction, see: (a) Yao, L.; Liu, K.; Tao, H.-Y.; Qiu, G.-F.; Zhou, X.; Wang, C.-J. Organocatalytic asymmetric desymmetrization: efficient construction of spirocyclic oxindoles bearing a unique allcarbon quaternary stereogenic center via sulfa-Michael addition. Chem. Commun. 2013, 49, 6078-6080. (b) Rautschek, J.; Jäger, A.; Metz, P. Formal Synthesis of (-)-Codeine by Application of Temporary Thio Derivatization. Org. Lett. 2018, 20, 832-835.

(16) For atroposelective thiol-Michael reactions, see: Maddox, S. M.; Dawson, G. A.; Rochester, N. C.; Ayonon, A. B.; Moore, C. E.; Rheingold, A. L.; Gustafson, J. L. Enantioselective Synthesis of Biaryl Atropisomers via the Addition of Thiophenols into Aryl-Naphthoquinones. ACS Catal. 2018, 8, 5443-5447.

(17) Kagan, H. B.; Fiaud, J. C. Kinetic Resolution. Top. Stereochem. 2007, 18, 249-330.
(18) Tan, Y.; Luo, S.; Li, D.; Zhang, N.; Jia, S.; Liu, Y.; Qin, W.; Song, C. E.; Yan, H. Enantioselective Synthesis of anti-syn-Trihalides and anti-syn-anti-Tetrahalides via Asymmetric $\beta$-Elimination. J. Am. Chem. Soc. 2017, 139, 6431-6436.

(19) Keith, J. M.; Larrow, J. F.; Jacobsen, E. N. Practical Considerations in Kinetic Resolution Reactions. Adv. Synth. Catal. 2001, 343, 5-26.

(20) (a) Tello-Aburto, R.; Harned, A. M. Palladium-Catalyzed Reactions of Cyclohexadienones: Regioselective Cyclizations Triggered by Alkyne Acetoxylation. Org. Lett. 2009, 11, 3998-4000. (b) Tello-Aburto, R.; Kalstabakken, K. A.; Volp, K. A.; Harned, A. M. Regioselective and stereoselective cyclizations of cyclohexadienones tethered to active methylene groups. Org. Biomol. Chem. 2011, 9, 7849-7859. (c) Tello-Aburto, R.; Kalstabakken, K. A.; Harned, A. M. Ligand and Substrate Effects During Pd-Catalyzed Cyclizations of Alkyne-Tethered Cyclohexadienones. Org. Biomol. Chem. 2013, 11, 5596-5604. (d) Zhang, J.; Wu, J.; Yin, Z.; Zeng, H.; Khanna, K.; Hu, C.; Zheng, S. An expedient stereoselective and chemoselective synthesis of bicyclic oxazolidinones from quinols and isocyanates. Org. Biomol. Chem. 2013, 11, 2939-2942. (e) Yin, Z.; Zhang, J.; Wu, J.; Liu, C.; Sioson, K.; Devany, M.; Hu, C.; Zheng, S. Double HeteroMichael Addition of $\mathrm{N}$-Substituted Hydroxylamines to Quinone Monoketals: Synthesis of Bridged Isoxazolidines. Org. Lett. 2013, 15, 3534-3537. (f) Smith, D. T.; Vitaku, E.; Njardarson, J. T. Dearomatization Approach to 2-Trifluoromethylated Benzofuran and Dihydrobenzofuran Products. Org. Lett. 2017, 19, 3508-3511.

(21) Examples of bifunctional thioureas in non-dynamic kinetic resolutions: (a) Berkessel, A.; Cleemann, F.; Mukherjee, S. Kinetic Resolution of Oxazinones: An Organocatalytic Approach to Enantiomerically Pure $\beta$-Amino Acids. Angew. Chem., Int. Ed. 2005, 44, 7466-7469. (b) Klauber, E. G.; De, C. K.; Shah, T. K.; Seidel, D. Merging Nucleophilic and Hydrogen Bonding Catalysis: An Anion Binding Approach to the Kinetic Resolution of Propargylic Amines. J. Am. Chem. Soc. 2010, 132, 13624-13626. (c) Mittal, N.; Sun, D. X.; Seidel, D. Kinetic Resolution of Amines via Dual Catalysis: Remarkable Dependence of Selectivity on the Achiral Cocatalyst. Org. Lett. 2012, 14, 3084-3087. (d) Min, C.; Mittal, N.; De, C. K.; Seidel, D. A dual-catalysis approach to the kinetic resolution of 1,2diaryl-1,2-diaminoethanes. Chem. Commun. 2012, 48, 10853-10855. (e) Roy, S.; Chen, K.-F.; Gurubrahamam, R.; Chen, K. Organocatalytic Kinetic Resolution of Racemic Secondary Nitroallylic Alcohols Combined with Simultaneous Desymmetrization of Prochiral Cyclic Anhydrides. J. Org. Chem. 2014, 79, 8955-8959. (f) Meninno, S.; Napolitano, L.; Lattanzi, A. Catalytic enantioselective synthesis of $\alpha$-nitroepoxides via aminolytic kinetic resolution. Catal. Sci. Technol. 2015, 5, 124-128. (g) Mittal, N.; Lippert, K. M.; De, C. K.; Klauber, E. G.; Emge, T. J.; Schreiner, P. R.; Seidel, D. A DualCatalysis Anion-Binding Approach to the Kinetic Resolution of Amines: Insights into the Mechanism via a Combined Experimental and Computational Study. J. Am. Chem. Soc. 2015, 137, 5748-5758.

(22) Ohkata, K.; Tamura, Y.; Shetuni, B. B.; Takagi, R.; Miyanaga, W.; Kojima, S.; Paquette, L. A. Stereoselectivity Control by Oxaspiro Ring during Diels-Alder Cycloadditions to Cross-Conjugated Cyclohexadienones: The Syn Oxygen Phenomenon. J. Am. Chem. Soc. 2004, 126, 16783-16792.

(23) (a) Rho, H. S.; Oh, S. H.; Lee, J. W.; Lee, J. Y.; Chin, J.; Song, C. E. Bifunctional organocatalyst for methanolytic desymmetrization of cyclic anhydrides: increasing enantioselectivity by catalyst dilution. Chem. Commun. 2008, 1208-1210. (b) Jang, H. B.; Rho, H. S.; Oh, J. S.; Nam, E. H.; Park, S. E.; Bae, H. Y.; Song, C. E. DOSY NMR for monitoring self aggregation of bifunctional organocatalysts: increasing enantioselectivity with decreasing catalyst concentration. Org. Biomol. Chem. 2010, 8, 3918-3922. (c) Oh, J.-S.; Lee, J.-W.; Ryu, T. H.; Lee, J. H.; Song, C. E. Self-association free bifunctional thiourea organocatalysts: synthesis of chiral $\alpha$-amino acids via dynamic kinetic resolution of racemic azlactones. Org. Biomol. Chem. 2012, 10, 10521055. 
(24) Ford, D. D.; Lehnherr, D.; Kennedy, C. R.; Jacobsen, E. N. Onand Off-Cycle Catalyst Cooperativity in Anion-Binding Catalysis. J. Am. Chem. Soc. 2016, 138, 7860-7863.

(25) For example: (a) Swiss, K. A.; Liotta, D. C.; Maryanoff, C. A. Mechanistic Aspects of the Ligand-Assisted Nucleophilic addition Reaction. J. Am. Chem. Soc. 1990, 112, 9393-9394. (b) Imbos, R.; Brilman, M. H. G.; Pineschi, M.; Feringa, B. L. Highly Enantioselective Catalytic Conjugate Additions to Cyclohexadienones. Org. Lett. 1999, 1, 623-626. (c) Moon, N. G.; Harned, A. M. Torsional Steering as Friend and Foe: Development of a Synthetic Route to the Briarane Diterpenoid Stereotetrad. Org. Biomol. Chem. 2017, 15, 1876-1888.

(26) Grayson, M. N.; Houk, K. N. Cinchona Urea-Catalyzed Asymmetric Sulfa-Michael Reactions: The Brønsted Acid-Hydrogen Bonding Model. J. Am. Chem. Soc. 2016, 138, 9041-9044, and references therein .

(27) Allman, T.; Goel, R. G. The basicity of phosphines. Can. J. Chem. 1982, 60, 716-722.

(28) Mitchell, A. S.; Russell, R. A. Oxidation with hypervalent iodine reagents. Part II: Novel cyclohexadienones as precursors for the synthesis of anthraquinones. Tetrahedron 1997, 53, 4387-4410.

(29) Berkessel, A.; Mukherjee, S.; Müller, T. N.; Cleemann, F.; Roland, K.; Brandenburg, M.; Neudörfl, J.-M.; Lex, J. Structural optimization of thiourea-based bifunctional organocatalysts for the highly enantioselective dynamic kinetic resolution of azlactones. Org. Biomol. Chem. 2006, 4, 4319-4330.

(30) Han, X.; Wang, Y.; Zhong, F.; Lu, Y. Enantioselective MoritaBaylis-Hillman reaction promoted by l-threonine-derived phosphinethiourea catalysts. Org. Biomol. Chem. 2011, 9, 6734-6740.

(31) Lou, Y.-P.; Zheng, C.-W.; Pan, R.-M.; Jin, Q.-W.; Zhao, G.; Li, Z. Enantioselective Direct Mannich Reactions of Cyclic $\beta$-Ketoesters Catalyzed by Chiral Phosphine via a Novel Dual-Reagent Catalysis. Org. Lett. 2015, 17, 688-691.

(32) Ji, X.; Cao, W.-G.; Zhao, G. Dual-reagent organophosphine catalyzed asymmetric Mannich reactions of isocyanoacetates with $\mathrm{N}$ -Boc-aldimines. Tetrahedron 2017, 73, 5983-5992.

(33) Yuan, K.; Song, H.-L.; Hu, Y.; Wu, X.-Y. Chiral phosphinothiourea-catalyzed asymmetric Morita-Baylis-Hillman reactions of acrylates with aromatic aldehydes. Tetrahedron 2009, 65, $8185-8190$.

(34) Sohtome, Y.; Tanatani, A.; Hashimoto, Y.; Nagasawa, K. Development of bis-thiourea-type organocatalyst for asymmetric Baylis-Hillman reaction. Tetrahedron Lett. 2004, 45, 5589-5592.

(35) Corey, E. J.; Decicco, C. P.; Newbold, R. C. Highly enantioselective and diastereoselective synthesis of $\beta$-amino acid esters and $\beta$-lactams from achiral esters and imines. Tetrahedron Lett. 1991, 32, 5287-5290.

(36) Le Gall, T.; Thetiot-Laurent, S. A.-L.; Nadal, B. Synthesis of Bis(tetronic acid)s via Double Dieckmann Condensation. Synthesis 2010, 1697-1701.

(37) Yakura, T.; Omoto, M.; Yamauchi, Y.; Tian, Y.; Ozono, A. Hypervalent iodine oxidation of phenol derivatives using a catalytic amount of 4-iodophenoxyacetic acid and Oxone as a co-oxidant. Tetrahedron 2010, 66, 5833-5840. 